\title{
Path Analysis on the Fad Diets and other Factors Affecting the Risk of Chronic Energy Deficiency among Adolescent Females at the Boarding School
}

\author{
Fitria Widhiyanti'), Yulia Lanti Retno Dewi²), Isna Qadrijati²) \\ 1)Masters Program in Public Health,Universitas Sebelas Maret \\ ${ }^{2)}$ Faculty of Medicine, Universitas Sebelas Maret
}

\section{ABSTRACT}

Background: Chronic Energy Deficiency (CED) is a state of lack of energy and protein intake that lasts for a long time continuously and causes health problems. The purpose of this study was to analyze the factors underlying the CED events in female students in boarding schools in Yogyakarta students.

Subjects and Method: This was an analytic observational study with a cross-sectional design. The study was conducted at the Yogyakarta Student Islamic Boarding School. A sample of 200 female adolescents aged 19-24 years was selected by simple random sampling. The dependent variable was CED. The independent variables were body image perception, energy intake, protein intake, fad diets, body mass index (BMI), stress, and nutritional knowledge. The data were measured by digital weight scale, microtoise, midline, and questionnaire. The data were analyzed by path analysis run on STATA 13.

Results: CED in female adolescent was directly increased with negative body image perception $(\mathrm{b}=0.83 ; 95 \% \mathrm{CI}=0.02$ to $1.65 ; \mathrm{p}=0.044), \mathrm{fad}$ $\operatorname{diet}(\mathrm{b}=1.37 ; 95 \% \mathrm{CI}=0.54$ to $2.21 ; \mathrm{p}<0.001)$, and severe stress $(b=1.94 ; 95 \% \mathrm{CI}=1.08$ to 2.82 ; $\mathrm{p}<$ 0.001). CED was directly decreased with high energy intake $(b=-1.18 ; 95 \% \mathrm{CI}=-1.99$ to -0.37 ; $\mathrm{p}=0.005)$, high protein intake $(\mathrm{b}=-1.20 ; 95 \%$ $\mathrm{CI}=-2.22$ to $-0.19 ; \mathrm{p}=0.020)$, high nutritional knowledge $(b=-0.83 ; 95 \% \mathrm{CI}=-1.62$ to $-0.05 ; \mathrm{p}=$ 0.038), and high BMI (b=-3.03; 95\% CI $=-5.15$ to $-0.90 ; p=0.005)$. CED was indirectly associated with fad diets and stress through BMI.

Conclusion: in female adolescent is directly increased with negative body image perception, fad diet, and stress. CED is directly decreased with high energy intake, high protein intake, high nutritional knowledge, and high BMI. CED is indirectly associated with fad diets and stress through BMI.

Keywords: chronic energy deficiency, fad diet, path analysis

\section{Correspondence:}

Fitria Widhiyanti. Masters Program in PublicHealth, Universitas Sebelas Maret. Jl. Ir. Sutami 36A, Surakarta 57126, Central Java. Email: fwidhiyanti@gmail.com. Mobile : +6282135793992

\section{Cite this as:}

Widhiyanti F, Dewi YLR, Qadrijati I (2020). Path Analysis on the Fad Diets and other Factors Affecting the Risk of Chronic Energy Deficiency among Female Adolescents at the Boarding School. J Matern Child Health. 5(3): 251-264. https://doi.org/10.26911/thejmch.2020.05.03.04

(c) (i) (-) Journal of Maternal and Child Health is licensed under a Creative Commons

\section{Attribution-Non Commercial-Share Alike 4.o International License.}

\section{BACKGROUND}

Teenagers are a time of very rapid changes in physical, cognitive and psychosocial growth. Adolescence is closely related to self-actualization. One of them is to recognize the perception of body image (body image). To get the ideal body shape judged by the environment, many young women go on a strict and uncontrolled diet, consume drinks or slimming drugs, drink herbal medicine, and so on. A diet that is carried out without a clear scientific basis can result in a decrease in nutritional status (Sayogo, 2011). Body image perception is a person's perception, thought, and feeling about their body shape (Grogan, 2016). Perception of body image is cate- 
gorized as positive and negative. Someone who has a positive perception of body image is satisfied with his body shape and appearance, feels confident, and accepts all changes in body shape.

Assessment of body image perception causes restrictions on consumption of certain nutritional content to get an ideal body image view according to the environment around adolescents rather than based on normal nutritional status. Incorrect body image perception can impact on a state of chronic nutrient deficiency. This situation is generally recognized as Chronic Energy Deficiency (CED) (Mulyani et al., 2016).

CED is a condition where a person in this case a teenager who suffers from chronic food shortages that causes chronic health problems with signs or symptoms including weak body and pale face (Mufidah et al., 2016).

The occurrence of CED is a result of environmental factors and human factors that are supported by a lack of intake of nutrients so that stored nutrients in the body are used to meet needs. If this situation lasts a long time then the nutrient stores will be exhausted and eventually a decline in tissue. Things that can cause the body to lack nutrients is the amount of nutrients consumed less, low quality or a combination of both. Nutrients consumed may also fail to be absorbed and used for the body (Mulyani et al., 2016).

CED is identified by proxy variables, such as deficits in anthropometry, and body composition or growth (Sahani et al., 2018). CED in women if not handled properly can be sustained during pregnancy, which can give birth to babies with low birth weight (LBW) and will carry the risk of death. The CED category in Indonesia is based on the measurement of mid upper arm circumference (MUAC) less than or equal to $23.5 \mathrm{~cm}$ or in the red section of the MUAC tape, if the measurement results are more than $23.5 \mathrm{~cm}$ then there is no risk of suffering from CED. Things that can cause the body to lack nutrients is the amount of nutrients consumed less, low quality or a combination of both. Nutrients consumed may also fail to be absorbed and used for the body (Mulyani et al., 2016).

Food intake is the amount of food a person consumes with the aim of getting a number of nutrients needed by the body. Every nutrient consumed will provide functions for the body, such as energy which is a source of energy to carry out activities Energy is a substance that is essential for humans in carrying out basal metabolism (vital body processes), carrying out activities, growth, and regulation (Hardiansyah et al., 2017).

The results of the Total Diet Survey (TDS) in 2014 showed that $45.7 \%$ of Indonesia's population consumed energy $\leq 70 \%$ of the energy adequacy rate or were in the very poor category (Zaki et al., 2017).

Protein is the most abundant substance in the body. The main function of protein is to build and maintain body tissue cells. Protein requirements in adolescents are influenced by the amount of protein needed to maintain lean body mass, plus the amount needed for additional lean body mass during adolescent growth. As with energy, growth is also influenced by protein intake. When protein intake is insufficient, there will be a decrease in growth, delay in sexual maturation, and reduced accumulation of lean body mass (Brown, 2011).

Fad diets is a term used for dietary methods that promise rapid, practical weight loss without having to exercise but are generally not based on a clear scientific basis so that safety is not guaranteed and various methods of fad diets lead someone to consume calories and nutrients low (Khawandanah and Tewfik, 2016). The fad diets method can have a negative clinical impact and the success effect of fad diets is only temporary (Collins, 2011). Various methods of fad diets lead 
someone to consume low calories and nutrients (Khawandanah and Tewfik, 2016).

Stress is a condition of inequality due to mismatch between physiological and psychological demands based on the situation from biological, psychological, and social sources that exist in individuals. Someone can feel depressed because the situation is considered dangerous or threatening (Sarafino et al., 2011).

Nutrition knowledge is knowledge about food and nutrients, sources of nutrients in food, safe food consumed so that it does not cause disease and how to process food well so that nutrients in food are not lost and how to live healthy (Dewi, 2017). On the other hand, knowledge can also be assessed based on the level of formal education that an individual has gone through (Tunurrohmin et al., 2019).

Islamic boarding schools at the beginning had a simple understanding, namely a place for students to study Islamic religious knowledge under the guidance of a teacher with the aim of preparing students as cadres of Islamic da'wah, who mastered Islam and were ready to spread religion Islam in various walks of life (Permenkes, 2013).

Along with the times, a fundamental change in the boarding school education system. These changes include the familiar madrasa system in the teaching and learning process and starting to teach general material. In the last two decades, the Islamic boarding school environment, in addition to the madrasa, also held public schools, colleges and community development programs. The teaching methods used are more innovative, creative, and can keep up with the times, such as methods of discussion, demonstration, debate, and so on. The education system in modern boarding schools strives to combine religious sciences with general sciences. Adolescents in Islamic boarding school are required to be able to master both of these sciences.

Based on data from the Global Nutrition Report sourced from WHO (2014), women with short and thin body with the largest short and thin body occurred in India, Bangladesh, Madagascar, Timor-Leste with a total of 1,415 million (Ieg, 2014). Global Nutrition Report (2018) states that underweight or low weight occurs in 9.7\% of women aged 20-49 years and $5.7 \%$ of young women aged $15-19$ years (Hawkes, 2018). This is due to a lack of nutrition in the form of not having enough food, not eating enough food that contains nutrients, as well as other direct and indirect causes.

The results of Riskesdas in 2018 showed that the proportion of CED in women of reproductive age was not pregnant, the proportion of Yogyakarta was above the average proportion of Indonesia ( $>14.5 \%)$. The proportion of CED in women of reproductive age who are not pregnant is still quite high occurring at the age of 20-24 years compared to the above age, which is $23.3 \%$. Women aged 15-49 have a CED risk in Indonesia of 24.2\% and in Yogyakarta women aged 15-49 who have a CED risk of $22.6 \%$ (Indonesian Ministry of Health, 2016).

\section{SUBJECTS AND METHOD}

\section{Study Design}

This was an analytic observational study with a cross-sectional design. The study was conducted at three Islamic Boarding Schools in Yogyakarta.

\section{Population and Sample}

The study population was female adolescents aged 19-24 years in Yogyakarta boarding school. A sample of 200 female adolescents was selected by simple random sampling.

\section{Study Variables}

The dependent variable was CED. The independent variables were body image perception, energy intake, protein intake, fad diets, stress, BMI, and nutritional knowledge. 
Widhiyanti et al./ Path analysis on the fad diets and other factors affecting CED

\begin{abstract}
4. Operational Definition of Variables CED was a condition of poor adolescent nutritional status caused by lack of food consumption of energy and protein sources characterized by the results of measurements of the mid upper arm circumference (MUAC). The data were measured by MUAC tape. The measurement scale was continous and transformed into dichotomous.
\end{abstract}

Body image perception was a level of satisfaction in the form of feelings towards body shape and appearance. The data were collected by questionnaire. The measurement scale was continous and transformed into dichotomous.

Energy intake was the amount of energy intake of adolescents based on recording the last 24 hours of food consumption. The data were measured by food recall. The measurement scale was continous and transformed into dichotomous.

Protein intake was the amount of protein intake of adolescents based on recording the last 24 hours of food consumption. The data were measured by food recall. The measurement scale was continous and transformed into dichotomous.

Fad diet was a diet that is prohibited, restricted or allowed by a certain amount by promising weight loss quickly and practically without having to exercise. The data were measured by food recall. The measurement scale was continous and transformed into dichotomous.

Stress was a condition of inequality due to mismatch between physiological and psychological demands experienced by adolescents during the past week. The data were collected by questionnaire. The measurement scale was continous and transformed into dichotomous.

Nutrition knowledge was adolescent knowledge about food and nutrients, sources of nutrients in food, safe food consumed, and how to process food well so that nutrients in food are not lost and how to live healthy. The data were collected by questionnaire. The measurement scale was continous and transformed into dichotomous.

\section{Study Instruments}

The instrument in this study was midline/ MUAC tape, digital weight scale, microtoise, and questionnaire.

\section{Data Analysis}

Univariate analysis was performed on each variables to determine the frequency distribution and sample characteristics. Bivariate analysis in this study used a cross-tabulation and chi-square test to determine the relationship between CEDs and independent variables. Multivariate analysis used was path analysis.

\section{Research Ethics}

The study was conducted using informed consent and research ethics. The research ethics was obtained by the Health Research Ethics Commission Dr. Moewardi General Hospital, Surakarta, Central Java, Indonesia at number 1,278/ XII/ HREC /2019.

\section{RESULTS}

\section{Sample Characteristics}

The frequency distribution of sample characteristics was showed in Table 1 . Table 1 showed that 110 female adolescents experienced CED (55\%) and 109 (54.5\%) female adolescents had negative body image.

\section{Bivariate analysis}

Table 2 shoed bivariate analysis on the associations between body image, energy intake, protein intake, fad diets, stress, BMI, nutritional knowledge, and CED.

Table 2 shows the results of bivariate analysis that negative body image $(\mathrm{OR}=4.29$; $\mathrm{p}<0.001)$, high fad $\operatorname{diet}(\mathrm{OR}=3.02 ; \mathrm{p}<0.001)$, and high stress levels $(\mathrm{OR}=6.96 ; \mathrm{p}<0.001)$ increase CED. CED decreased with high energy intake $(\mathrm{OR}=0.18 ; \mathrm{p}<0.001)$, high protein intake $(\mathrm{OR}=0.45 ; \mathrm{p}=0.021)$, and high nutritional knowledge $(\mathrm{OR}=0.52 ; \mathrm{p}=0.028)$. 
Table 1. Sample Characteristics

\begin{tabular}{llcc}
\hline \multicolumn{1}{c}{ Characteristics } & n & \% \\
\hline CED Status & Not CED & 90 & 45.0 \\
BMI $\left(\mathbf{k g B W} / \mathbf{m}^{2}\right)$ & CED & 110 & 55.0 \\
& Underweight $(<18.5)$ & 35 & 17.5 \\
Body Image & Normal $(\geq 18.5)$ & 165 & 82.5 \\
& Positive (score $<38)$ & 109 & 54.5 \\
Energy Consumption & Negative (score $\geq 38)$ & 91 & 45.5 \\
Protein Intake & Low & 130 & 65.0 \\
& High & 70 & 35.0 \\
Fad Diets & Low & 157 & 78.5 \\
\multirow{3}{*}{ Stress } & High & 43 & 21.5 \\
& No & 121 & 60.5 \\
Nutritional Knowledge & Yes & 79 & 39.5 \\
& Low (score $<14)$ & 121 & 60.5 \\
& High (score $\geq 14)$ & 79 & 39.5 \\
& Poor (score $<60 \%)$ & 72 & 26.0 \\
\hline
\end{tabular}

Table 2. Bivariate analysis on the effects of body image, energy intake, protein intake, fad diets, stress, nutritional knowledge, and BMI on CED

\begin{tabular}{|c|c|c|c|c|c|c|}
\hline \multirow{3}{*}{ Independent Variables } & \multicolumn{4}{|c|}{ CED } & \multirow{3}{*}{ OR } & \multirow{3}{*}{$\mathbf{p}$} \\
\hline & \multicolumn{2}{|c|}{ No CED } & \multicolumn{2}{|c|}{ CED } & & \\
\hline & $\mathbf{n}$ & $\%$ & $\mathbf{n}$ & $\%$ & & \\
\hline \multicolumn{7}{|l|}{ Body Image } \\
\hline Positive & 66 & 60.55 & 43 & 39.45 & 4.29 & $<0.001$ \\
\hline Negative & 24 & 26.37 & 67 & 73.63 & & \\
\hline \multicolumn{7}{|l|}{ Energy Consumption (\%) } \\
\hline Low $(<100 \%)$ & 40 & 30.77 & 90 & 69.23 & 0.18 & $<0.001$ \\
\hline High $(\geq 100 \%)$ & 50 & 71.43 & 20 & 28.57 & & \\
\hline \multicolumn{7}{|l|}{ Protein Intake (\%) } \\
\hline Low (<100\%) & 64 & 40.76 & 93 & 59.24 & 0.45 & 0.021 \\
\hline High ( $\geq 100 \%)$ & 26 & 60.47 & 17 & 39.53 & & \\
\hline \multicolumn{7}{|l|}{ Fad Diets } \\
\hline No & 67 & $55 \cdot 37$ & 54 & 44.63 & 3.02 & $<0.001$ \\
\hline Yes & 23 & 29.11 & 56 & 70.89 & & \\
\hline \multicolumn{7}{|l|}{ Stress } \\
\hline Low $(<14)$ & 75 & 61.98 & 46 & 38.02 & 6.96 & $<0.001$ \\
\hline $\operatorname{High}(\geq 14)$ & 15 & 18.99 & 64 & 81.01 & & \\
\hline \multicolumn{7}{|l|}{ Nutritional Knowledge } \\
\hline Low $(<60)$ & 25 & 34.72 & 47 & 65.28 & 0.52 & 0.028 \\
\hline $\operatorname{High}(\geq 60)$ & 65 & 50.78 & 63 & 49.22 & & \\
\hline \multicolumn{7}{|l|}{ BMI } \\
\hline Normal $\left(<18.5 \mathrm{~kg} / \mathrm{m}^{2}\right)$ & 1 & 1.11 & 34 & 30.91 & 0.03 & $<0.001$ \\
\hline Overweight $\left(\geq 18.5 \mathrm{~kg} / \mathrm{m}^{2}\right)$ & 89 & 98.89 & 76 & 69.09 & & \\
\hline
\end{tabular}


Widhiyanti et al./ Path analysis on the fad diets and other factors affecting CED

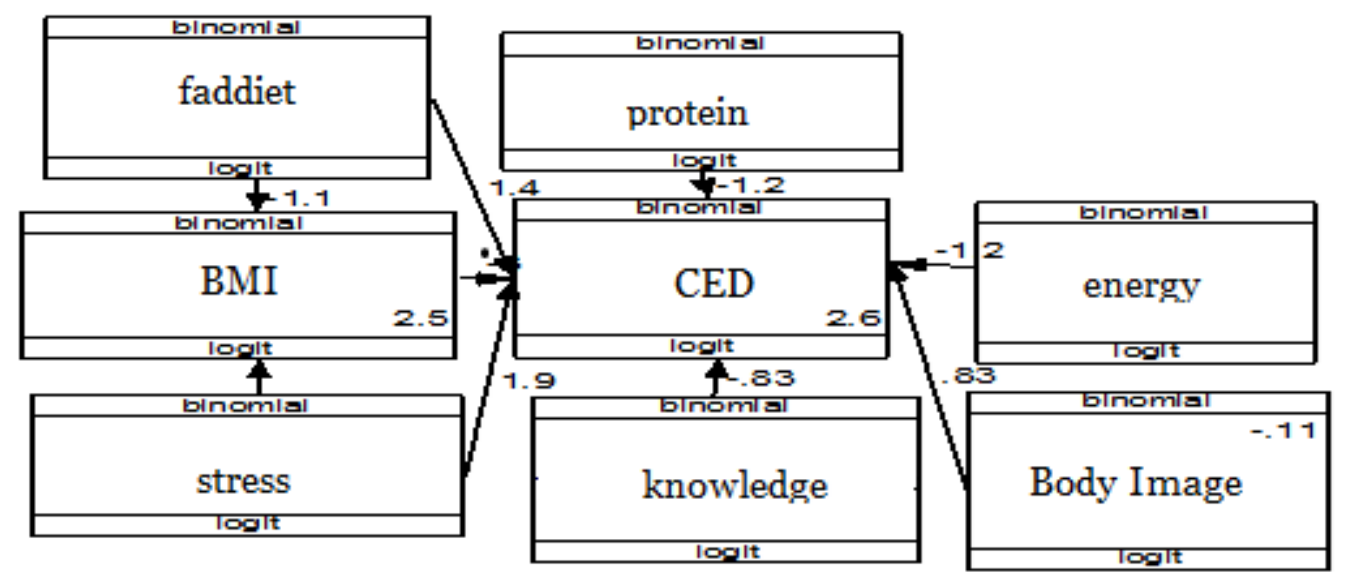

Figure 1. Path Analysis model on CED as the dependent variable

Table 3. Results of path analysis on the relationships between body image perception, energy intake, protein intake, fad diet, BMI, stress, nutritional knowledge, and CED

\begin{tabular}{|c|c|c|c|c|c|}
\hline \multirow[b]{2}{*}{$\begin{array}{c}\text { Dependent } \\
\text { variable }\end{array}$} & \multirow[b]{2}{*}{ Independent variable } & \multirow{2}{*}{$\begin{array}{l}\text { Path } \\
\text { Coeff. } \\
\text { (b) }\end{array}$} & \multicolumn{2}{|c|}{$95 \%$ CI } & \multirow[b]{2}{*}{$\mathbf{p}$} \\
\hline & & & $\begin{array}{l}\text { Lower } \\
\text { Limit }\end{array}$ & $\begin{array}{l}\text { Upper } \\
\text { Limit }\end{array}$ & \\
\hline \multicolumn{6}{|c|}{ Indirect Effect } \\
\hline \multirow[t]{7}{*}{ CED Status } & $\leftarrow$ Body image perception (negative) & 0.83 & 0.02 & 1.65 & 0.044 \\
\hline & $\leftarrow$ Energy intake (high) & -1.18 & -1.99 & -0.37 & 0.005 \\
\hline & $\leftarrow$ Protein intake (high) & -1.20 & -2.22 & -0.19 & 0.020 \\
\hline & $\leftarrow$ Fad diets (yes) & 1.37 & 0.54 & 2.21 & 0.001 \\
\hline & $\leftarrow$ Stress $($ score $\geq 14$ ) & 1.94 & 1.08 & 2.82 & $<0.001$ \\
\hline & $\leftarrow$ Nutritional knowledge (score $\geq 60$ ) & -0.83 & -1.62 & -0.05 & 0.038 \\
\hline & $\leftarrow \mathrm{BMI}\left(\geq 18.5 \mathrm{kgBW} / \mathrm{m}^{2}\right)$ & -3.03 & -5.15 & -0.90 & 0.005 \\
\hline \multicolumn{6}{|c|}{ Indirect Effect } \\
\hline $\mathrm{BMI}(\geq 18.5$ & $\leftarrow$ Fad diets (yes) & -1.05 & -1.82 & -0.29 & 0.007 \\
\hline $\left.\mathrm{kgBW} / \mathrm{m}^{2}\right)$ & $\leftarrow$ Stress $($ score $\geq 14)$ & -0.92 & -1.67 & -0.16 & 0.018 \\
\hline \multicolumn{6}{|c|}{$\mathrm{N}$ observation $=200$} \\
\hline
\end{tabular}

\section{Path Analysis}

The result of path analysis model was depicted in Figure 1. Figure 1 showed direct and indirect associations between variables. Table 3 showed the results of path analysis on the relationships between body image perception, energy intake, protein intake, fad diet, BMI, stress, nutritional knowledge, and CED.

Table 3 showed negative body image perception $(\mathrm{b}=0.83$; $95 \% \mathrm{CI}=0.02$ to 1.65 ; $\mathrm{p}=0.044)$, fad $\operatorname{diet}(\mathrm{b}=1.37 ; 95 \% \mathrm{CI}=0.54$ to
$2.21 ; \mathrm{p}<0.001)$, and high stress $(\mathrm{b}=1.94 ; 95 \%$ $\mathrm{CI}=1.08$ to $2.82 ; \mathrm{p}<0.001$ ) directly increased the risk of CED in female adolescents.

High energy intake $(b=-1.18 ; 95 \% \mathrm{CI}=-$ 1.99 to $-0.37 ; \mathrm{p}=0.005$ ), high protein intake $(\mathrm{b}=-1.20 ; 95 \% \mathrm{CI}=-2.22$ to $-0.19 ; \mathrm{p}=0.020)$, high knowledge on nutrition $(b=-0.83$; $95 \%$ $\mathrm{CI}=-1.62$ to $-0.05 ; \mathrm{p}=0.038)$, and $\mathrm{BMI} \geq 18.5$ $\mathrm{kgBW} / \mathrm{m}^{2}(\mathrm{~b}=-3.03$; 95\% $\mathrm{CI}=-5.15$ to -0.90 ; $\mathrm{p}=0.005$ ) directly decreased the risk of CED in female adolescents.

Fad diet $(b=-1.05 ; 95 \% \mathrm{CI}=1.82$ to - 
Widhiyanti et al./ Path analysis on the fad diets and other factors affecting CED

$0.29 ; \mathrm{p}=0.007)$ and stress $(\mathrm{b}=-0.92 ; 95 \%$ $\mathrm{CI}=-1.67$ to $-0.16 ; \mathrm{p}=0.018$ ) were indirectly and negatively associated with CED through BMI.

\section{DISCUSSION
1. The effect of body image perception on CED}

The results show that there was a direct effect of body image perception on the risk of CED. Female adolescent with negative body image perception had possibility (logodd) to experience CED o.83 units higher than those with positive body image perception.

Nugroho (2018) showed that adolescents with mild dissatisfaction decreased good nutritional status 0.30 times $(\mathrm{OR}=$ $0.30 ; \mathrm{p}=0.005$ ).

There are two factors that influence the body image with adolescent nutritional status, namely the perceived pressure to gain muscle in young men and the pressure felt to lose weight in adolescent girls and social influences, such as social comparisons, small talk, and bullying about body weight (Voelker et al., 2015).

Body image is a person's perception of their body shape and size. At the age of adolescence a new element will emerge, namely awareness of personality and body life so that young women begin to pay attention to their physical appearance. Incorrect perception of adolescent body image will cause teens to use various dietary techniques (Mase et al., 2015). In general, dissatisfaction with body shape arises so that young women tend to make an effort to gain the desired weight. Body image is closely related to self-confidence (Normate et al., 2017).

One of the ways taken to get the ideal body through subjective assessment based on the surrounding environment is to lose weight. This assessment is subjective so it is not based on normal conditions in accordance with adolescent nutritional needs. This causes young women to experience lack of nutrient intake, especially energy intake and protein intake, thereby increasing the problem of CED nutrition in young women.

\section{The effect of energy intake on CED}

The results show that there was a direct effecr of energy intake on the risk of CED. Female adolescent with high energy intake had possibility (logodd) to experience CED 1.18 units lower than those with low energy intake.

Rachmawati et al. (2019) stated that there was a relationship between CED and food intake. Women with low food intake are more likely to experience CED $(b=-2.74 ; 95 \%$ CI -7.74 to -1.28; $\mathrm{p}=0.006$ ).

In this study, it was found that adolescent girls did not meet the needs of daily food intake due to a solid routine as a student and boarding school students. Not a few of those who missed their eating schedule because they are tired from activity and prefer to rest. Generally the female adolescents only consume modest snacks and do not pay attention to the amount of energy intake needed in a day to move. Changes in nutrition in adolescents if not carried out improvements that are pursued properly, will affect the quality of society in the future (Said et al., 2020).

\section{The effect of protein intake on CED}

There was a direct effect of protein intake on the risk of CED. Female adolescents with high protein intake had logodd to experience CED 1.20 unit lower than those with low protein intake.

Arista (2017) stated that there is an influence on the amount of protein intake in predicting the incidence of CED ( $p<0.001)$. Research conducted by Sirajuddin (2010) states that there is a relationship between protein intake and CED in adult women in South Sulawesi. The smaller the protein intake, the greater the risk of CED events, and vice versa. The magnitude of risk in adult women with protein intake $<80 \%$ RDA compared to those who have a protein intake> 
$80 \% \mathrm{RDA}$ is 1,163 times higher. It means that if someone is exposed to low protein intake, they will have a greater chance of suffering from CED.

Increased protein intake is related to eating habits or food consumption patterns. The pattern of food consumption with high animal or vegetable side dish components is a precondition for better protein intake. This is due to the source of protein in the composition of dishes is a characteristic of side dishes as a source of protein.

The condition of the students' boarding school in this study did not provide facilities for the consumption of the boarding school food consumption, so that the amount of santri nutrition intake, especially protein intake, could not be monitored by the cottage and could not be provided according to the needs of the students. The absence of nutrition providers in the cottage is one of the factors in the low protein intake of adolescents. Low protein intake should be overcome by organizing the consumption of cottage meals so that the amount of nutrients, especially protein intake can be given according to the nutritional needs of adolescents.

In line with the principle of nutritional intake with a person's nutritional status, if adequate protein intake, nutritional status will be good, including the size of the upper arm circumference (MUAC). Theoretically, protein intake is related to the size of the upper arm circumference. If enough protein is consumed, protein will function as the last alternative energy after carbohydrates and fats are used. This means that the dominance of protein as an energy source will be done as a compensation for energy deficit to reduce the incidence of CED (Guyton et al., 2008).

Attention needs to be paid to aspects of adolescent nutritional needs and intake, due to changes in adolescent lifestyle and eating habits (Marine et al., 2015).

Nutrient intake in food eaten daily has a big influence on the nutritional status of individuals, due to the balance of nutrient intake which affects nutritional problems. Nutrients that are consumed must be in harmony and meet the body's needs (Almatsier, 2011).

\section{The effect of fad diets on CED}

There is a direct influence of fad diets on the risk of female adolescents experiencing CED. female adolescents who did fad diets were more likely (logodd) to experience CED 1.37 units higher than those who did not do fad diets.

Nurjannah et al. (2019) stated that the low level of energy and nutrient adequacy is a result of dietary efforts with fad diets. The proportion of respondents who have a sufficient level of energy and macro nutrients in the category of less and do fad diets is higher than the respondents whose level of energy and nutrient sufficiency is categorized as sufficient and more.

Haq et al. (2018) found that most of the young women who work as models have adequate levels of energy and macro nutrients under the RDA and use the fad diets method, which is to reduce the frequency of eating to 2 times a day and avoid the consumption of carbohydrates, proteins, and fats so that they only consume fruit and vegetable.

Eating disorders experienced by adolescents associated with the type of weight loss efforts undertaken. The diet taken by these teenagers is mostly an unhealthy diet which is often referred to as fad diets (Sulistyan et al., 2016). Weight loss from the fad diets method generally occurs very quickly, but most of the weight loss is water and muscle rather than fat tissue so that it can have a "yo-yo" effect (Kim et al., 2015). Extreme weight loss followed by rapid weight gain is associated with many health risk factors, such as heart disease, cancer, diabetes, increased LDL cholesterol, and reduced muscle mass (McNight, 2017). 
Widhiyanti et al./ Path analysis on the fad diets and other factors affecting CED

Malnutrition in this case CED is a condition of poor nutrition that results from a reduction in macro nutrient intake or metabolic disorders. MUAC is an important indicator for simple screening of the nutritional status of adults, especially in developing countries (Bhattacharya et al., 2019).

Fad diets have an indirect effect on the risk of young women experiencing CED through BMI. Female adolescents who did fad diets had a lower logodd to get BMI $\geq 18.5$ $\mathrm{kgBW} / \mathrm{m} 2$ of 1.05 units lower than those who did not have fad diets.

Sulistyan et al. (2016) found that a number of 51 respondents (42.5\%) were or had ever attempted weight loss and 47 people (92.2\%) of them sought weight loss using the fad diets method.

Adolescent girls often compare their body shapes with those of friends around them and are easily influenced by the body shapes of people around them. The problem that occurs is that the body shape seen by these teenagers is not always a picture of a body that has normal nutritional status. The average BMI values of the models displayed in the mass media are far below normal BMI and can be categorized as very thin body shapes (Dittmar, 2007).

\section{The effect of stress on CED}

There was a direct effect of stress on the risk of CED. Female adolescents with severe stress had logodd to experience CED 1.94 units higher than those with mild stress.

Gamayanti et al. (2018) states that $81.54 \%$ of students who work on thesis experience stress. $54.3 \%$ of subjects experienced changes in eating behavior when completing the final project. More than $50 \%$ of subjects have a lack of nutrients, both energy, carbohydrates, and protein. Chronic stress that is stress that occurs every day for a long period of time, will involve the pituitary-adrenalcorticol system, where the hypothalamus will secrete CRH which decreases appetite (Sominsky, 2014). If the low energy and protein intake lasts for a long time and is not immediately addressed it can cause CED events in young women.

Psychology Foundation of Australia states that psychological disorders such as depression, anxiety and stress are thought to be one of the risk factors for the occurrence of nutritional problems both in childhood and appear after adulthood. Various forms of stressors can trigger depression, anxiety, and stress in school-aged children. This can be in the form of stressors who come from the family, the school environment, both stressors from academic activities, teachers and school friends (Psychology Foundation of Australia, 2014).

The young women in this study undergo a daily routine of being a student as well as being a boarding school santri. Stressors experienced in the form of academic demands lectures and boarding schools. This causes more stress levels of adolescent girls in heavy categories.

Stress that is not managed properly can cause disruption of hormonal balance, depletion of vitamins and minerals and weakening the immune system. Stressful conditions will stimulate excessive expenditure of adrenaline, causing the heart to beat hard and fast. The hormone adrenaline is produced in large quantities during conditions of anger and stress. Some people experience loss of appetite and weight during stress. The digestive system of stress sufferers may be disrupted so that sufferers do not have appetite because they feel nausea and vomiting (Tirta, 2010).

Stress has an indirect effect on the risk of adolescent girls experiencing CED through BMI. Adolescent girls with severe stress levels were (logodd) likely to have a BMI of 0.92 lower units than young women with mild stress levels $(b=-0.92 ; 95 \% \mathrm{CI}=-1.67$ to 
Widhiyanti et al./ Path analysis on the fad diets and other factors affecting CED

-o.16; $\mathrm{p}=0.016)$. Stress has an indirect effect on the risk of adolescent girls experiencing CED through BMI. Young women with severe stress levels were less likely to have a BMI than young women with mild stress levels $(b=-0.92 ; 95 \% C I=-1.67$ to $-0.16 ; p=0.016)$.

Purwanti et al. (2017) at the Faculty of Medicine at Tanjungpura University in Pontianak showed that there was a significant relationship between stress level and body mass index in students $(\mathrm{r}=0.73 ; \mathrm{p}<0.001)$.

There are 2 types of dietary changes due to stress. There are individuals who are in a state of stress consuming more food (emotional eaters) and conversely there are individuals who are in a state of stress whose diet is not affected or reduced (non-emotional eaters) (Sominsky, 2014).

This study found that teenage girls in boarding schools in Yogyakarta students with high stressors in the form of academic demands for lectures and demands for boarding schools can cause a decrease in appetite. Decreased appetite causes a decrease in BMI in young women. Disturbed appetite causes the amount of nutrient intake, especially energy and protein intake also changes. Decreasing the amount of energy intake and protein intake can cause nutritional problems in young women, namely CED.

\section{The effect of nutritional knowledge on CED}

There was a direct effect of nutritional knowledge on the risk of CED. Female adolescents with high knowledge toward nutrition had logodd to experience CED o.83 units lower than those with low knowledge toward nutrition.

The results of this study are in line with Rachmawati et al. (2019) which states that there is a statistically significant relationship between knowledge and CED, the higher the knowledge, the lower the risk of CED ( $b=-$ 2.32; 95\% $\mathrm{CI}=-6.27$ to $-0.52 ; \mathrm{p}=0.020)$.

Gemada et al. (2013) stated that there was a relationship between knowledge and the incidence of CED. Malnutrition can occur due to lack of knowledge possessed.

Someone who has more knowledge about the nutritional status needed will be more careful in determining the type of food to be consumed (Wong et al., 2018). Good knowledge can also form positive behaviors that will be applied in everyday life, especially in eating patterns (Mangg Stephani et al., 2020).

A person's level of nutritional knowledge will influence attitudes and behavior in food selection. Knowledge is obtained not only from formal education, but can be obtained through health workers, print media, and electronic media. The higher the level of education or knowledge, the easier it is for someone to receive information about nutrition so that knowledge about nutrition will be better (Ervinawati et al., 2019).

Female adolescents who living in islamic boarding school in Yogyakarta were came from various universities. With a high level of education, it is expected that the knowledge of adolescent nutrition is high so that adolescent nutrition problems can be overcome.

As many as 40.00\% female adolescents had moderate knowledge toward nutrition. The number of adolescent girls with insufficient nutritional knowledge is still quite a lot, this is due to the indifference of adolescents to the need for nutritional intake, causing the CED.

\section{The effect of BMI on CED}

There was a direct effect of BMI on the risk of CED. Female adolescents with BMI $\geq 18.5$ $\mathrm{kgBW} / \mathrm{m}^{2}$ had logodd to experience CED 3.03 unit lower than those with BMI $<18.5$ $\mathrm{kgBW} / \mathrm{m}^{2}$.

Kalsum et al. (2014) found that BMI was used to assess the nutritional status of adults, where CED status was measured with $\mathrm{BMI}<18.5$. BMI is currently considered the 
best indicator for assessing adult nutritional status because it uses two growth indicators, namely body weight (a measure of tissue mass growth) and height (a measure of linear growth).

Anthropometric index that is commonly used in adults (aged 18 years and over) is the body mass index (BMI). BMI is a simple tool for monitoring nutritional status specifically related to underweight and overweight.

The incidence of CED in female adolescent increases with the perception of negative body image, fad diets, and severe stress level. The incidence of CED decreases with high energy intake, high protein intake, high nutritional knowledge, and high BMI. There is an indirect effect of fad diets and stress on CED through BMI.

\section{AUTHOR CONTRIBUTION}

Fitria Widhiyanti is the main researcher who plays a role in collecting and processing data. Yulia Lanti Retno Dewi examined the conceptual framework and methodology. Isna Qadrijati examined the draft.

\section{CONFLICT OF INTEREST}

There is no conflict of interest in this study.

\section{FUNDING AND SPONSORSHIP}

There was no external funding.

\section{ACKNOWLEDGEMENT}

We would like to thank the Islamic Boarding School students in Yogyakarta, for giving permission to collected the data from female adolescents.

\section{REFERENCE}

Arista AD, Widajanti ISM (2017). Hubungan pengetahuan, sikap, tigkat konsumsi energi, protein, dan indeks massa tubuh/umur dengan Kurang energi kronik pada remaja putri (The relationship of knowledge, attitudes, levels of energy consumption, protein, and body mass index / age with chronic lack of energy in young women). JKM E-Journal, 5(4): 585-591. Retrieved from: http://ejournal3.undip.ac.id/index.php/$\mathrm{jkm}$.

Bhattacharya A, Pal B, Mukherjee S, Roy SK (2019). Assessment of nutritional status using anthropometric variables by multivariate analysis. BMC Public Health, 19(1): 9-11. https://doi.org/10.1186/s12889-0197372-2

Brown JE (2011). Nutrition through the life cycle 3rd edition. New York: Wadsworth Inc.

Collins C (2011). Dietary strategies for successful weight loss and maintenance: More evidence required. J Am Diet Assoc, 11(12): 1822-1825. https://doi:10.1016/j.jada.2011.09.016

Dewi PLP (2017). Hubungan pengetahuan gizi, aktivitas fisik dan asupan energi, asupan lemak dengan kejadian obesitas pada remaja Sekolah Menengah Pertama (The relationship of nutritional knowledge, physical activity and energy intake, fat intake with the incidence of obesity in junior high school adolescents). Jonuai, 6(3): 257-261. https:// doi.org/10.14710/jnc.v6i3.16918

Dittmar H (2007). Consumer culture, identity and well-being: the search for the good life and the body perfect. London: Psychology PressRetrieved from:https: //searchworks.stanford.edu/view/7096 411

Ervinawati E, Wirda ANN (2019). Determinant of chronic energy manutrition (CEM) in pregnant woman at Lubuk Muda Public Health Center. Jurnal Kesehatan Komunitas, 4(3): 120-125. doi: 10.25311/keskom. vol4.iss3.289.

Gamayanti W, Mahardianisa IS (2018). Self disclosure dan tingkat stres pada mahasiswa yang sedang mengerjakan skripsi. Psympathic, Jurnal Ilmiah Psikologi, 
Widhiyanti et al./ Path analysis on the fad diets and other factors affecting CED

5(1): 115-130.doi: 10.15575/psy.v5i1.2282

Gemada D, Beyene F, Garoma W, Fekadu H (2013). Assessment of nutritional practices of pregnant mothers on maternal. STAR Journal, 2(3), 105-113. https:// doi.org/10.4314/star.v2i3.98748

Grogan S (2016). Body image: Understanding body dissatisfaction in men, women, and children (3rd ed). New York: Routledge.

Guyton H (2008). Bahan ajar fisiology kedokteran. Jakarta:EGC.

Haq AB, Murbawani EA (2014). Status gizi, asupan makan remaja akhir yang berprofesi sebagai model (Nutritional status, eating intake of late teens who work as models). Jonuai, 3(4): 489494. https://doi.org/10.14710/jnc.v3i4.6841

Hardiansyah M, Supariasa I (2017). Ilmu gizi teori dan aplikasi (Nutrition theory and application). Jakarta: PT Raja Grafindo Persada.

Hawkes C (2018). Global nutrition report about the global nutrition report. Retrieved from: https://globalnutritionreport.org/reports/globanutrition-report2018/

Ieg (2014). Global nutrition report. in global nutrition report. Retrieved from: http://dx.doi.org/10.2499/9780896295643

Kalsum U, Sutrisna B, Djuwita R, Achadi EL, Jahari AB (2014). A new alternative indicator for Chronic Energy Deficiency in women of childbearing age in Indonesia. 5(2) Retrieved from: https://scholar.ui.ac.id/en/publications/anew-alternative-indicator-for-chronicenergy-deficiency-in-wome

Ministry of Health RI (2016). Status gizi di Indonesia, pusat dan data informasi (Nutritional status in Indonesia, center and information data). Retrieved from: http://www.depkes.go.id/folder/view.
Khawandanah J, Tewfik I (2016). Fad diets: lifestyle promises and health challenges, 5(6): 80-94. https://doi.org/10.5539/jfr.v5n6p8o

Kim MH, Kim Y, Chung J, Yeon JY (2015). Fad diet status of male and female collegians. Korean J Food \& Nutr, 28(2): 258-268. https://doi.org/10.9799/ksfan.2015.28.2.258.

Manggabarani S, Said I, Hadi AJ (2020). The effectivity of peer education module on knowledge, attitude, and fast food consumption in adolescents. J Health Promot Behav. 5(1): 11-17. Retrieved from: https://thejhpb.com/index.php?journal=thejhpb\&page $=$ article\&op=view\&path $\% 5 \mathrm{~B} \% 5 \mathrm{D}=231$

Marine D, Adiningsih S (2015). Perbedaan Pola konsumsi dan status gizi antara remaja dengan orang tua Diabetes Melitus dan Non Diabetes Melitus (Differences in consumption patterns and nutritional status between adolescents and parents with Diabetes Mellitus and Non Diabetes Mellitus). Media Gizi Indonesia, 10(1): 179-183. http://dx.doi.org/10.20473/mgi.v10i2.179-183

Mase T, Miyawaki C, Ohara K, Nakamura H (2015). The relationships among perception of body image, a desire for thinness, and dieting behavior in young females in Japan. Health. 7(1): 112-118. doi: 10.4236/health.2015.71013. 112118.

McNight C (2017). Health risks of yo-yo dieting. Retrieved from: http://www.livestrong.com/article/353915-health-risksof-yoyo-dieting

Mufidah R, Rahayuning D (2016). Hubungan tingkat kecukupan energi, tingkat aktivitas fisik dan karakteristik keluarga dengan risiko kekurangan energi kronis pada ibu hamil di wilayah kerja Puskesmas Dawe, Kudus (The relationship between the level of energy suffi- 
Widhiyanti et al./ Path analysis on the fad diets and other factors affecting CED

ciency, the level of physical activity and family characteristics with the risk of chronic energy shortages in pregnant women in the work area of the Dawe Health Center, Kudus). JKM, 4(4): 545-551. Retrieved from: https://ejournal3.undip.ac.id/index.php/jkm/article/view/14285

Mulyani I, Amir S, Astuti NFW (2016). Persepsi body image dan pola makan terkait terjadinya KEK pada siswa SMA IT Abu Bakar Yogyakarta (Body image and eating pattern perception related to CED occurrence at IT Abu Bakar Yogyakarta High School students). FGD. Yogyakarta: FK UGM.Retrieved from:https:// www.academia.edu/36503066/PersepsiBody_Image_dan_Pola_Makan_Terkait_Terjadinya_Kurang_Energi_Kronik_KEK_pada_Siswa_Sekolah_Menengah_Atas_IT_Abu_Bakar_Yogyakarta

Normate ES, Nur ML, Toy SM (2017). Hubungan teman sebaya, citra tubuh dan pola konsumsi dengan status gizi remaja putri (Peer relationships, body image and consumption patterns with the nutritional status of adolescent girls). Unnes Journal of Public Health, 6(3): 141. https://doi.org/10.15294/ujph.v6i3.17016

Nugroho RF (2018). Hubungan stres psikososial, persepsi bentuk tubuh, eating disorder dan pola makan dengan status gizi pada remaja putri (Relationship of psychosocial stress, body shape perception, eating disorder and eating patterns with nutritional status in young women). Jurnal Keperawatan Soedirman, 13(2): 92-99.doi : 10.20884/1.jks.2018.13.2.841

Nurjannah I, Muniroh L (2019). Body image, tingkat kecukupan zat gizi, dan fad diets pada model remaja putri di Surabaya (Body image, nutrient adequacy level, and fad diets on the teenage girl model in Surabaya). MGI, 14(1): 95105. https://doi.org/10.204736/mgi.v14i1.95-105

Permenkes RI (2013). Permenkes RI Nomor I tentang Pedoman penyelenggaraan dan pembinaan pos kesehatan pesantren (Republic of Indonesia Minister of Health Regulation Number I regarding Guidelines for organizing and fostering boarding school health posts Republic of Indonesia Minister of Health Number I regarding Guidelines for organizing and fostering boarding school health posts). Retrieved from: http://ditjenpp.kemenkumham.go.id/arsip/bn/2013/bn163-2013lamp.pdf

Psychology Foundation of Australia (2014). Depression anxiety stress scales. Retrieved from:http://www2.psy.unsw.edu.au/dass/Indonesian/Damanik.htm Rachmawati NC, Dewi YLR, Widyaningsih V (2019). Multilevel analysis on factors associated with occurrence chronic energy deficiency among pregnant women. J Matern Child Health, 4(6): 474485. https://doi.org/10.26911/thejmch.2019.04.06.08

Riskesdas (2018). Hasil utama riset kesehatan dasar (Riskesdas) (Main results of basic health research (Riskesdas)). Retrieved from:https://www.kemkes.go.id/resources/download/infoterkini/hasilriskesdas-2018.pdf

Sahani R, Gautam RK, Golnabi AH, Vedwan $\mathrm{N}$ (2018). Comparative study of chronic energy deficiency among adult males of Andaman and Nicobar Islands and their counterparts. Sciendo 81(1): 1-17. https://doi.org/10.2478/anre20180001

Said I, Hadi AJ, Manggabarani S, Tampubolon IL, Maryanti E, Ferusgel A (2020). The effectivity of nutrition education booklet on knowledge, fast-food consumption, calorie intake, and Body 
Widhiyanti et al./ Path analysis on the fad diets and other factors affecting CED

Mass Index in Adolescents. $\mathrm{J}$ Health Promot Behav, 5(1): 11-17.https://doi.org/10.26911/thejhpb.2020.05.01.02

Sarafino E, Timothy W (2011). Health psychology biopsychosocial interaction seventh edition.United States of America.

Sayogo S (2011). Gizi Remaja Putri (Young Women Nutrition). Jakarta: Balai Penerbit FK UI.

Sominsky LSS (2014).Eating behavior and stress: a pathway to obesity. Frontiers in Psychology 5: 434.doi: 10.3389/fpsyg.2014.00434

Sulistyan A, Huryati E, Hastuti J (2016). Distorsi citra tubuh, perilaku makan, dan fad diets pada remaja putri di Yogyakarta (Body image distortion, eating behavior, and fad diets in young women in Yogyakarta). Jurnal Gizi Klinik Indonesia, 12(3): 99-107. Retrieved from: https://jurnal.ugm.ac.id/jgki/article/view/22 644 .

Tirta MPLK (2010). Status stres psikososial dan hubungannya dengan status gizi siswa SMP Stella Duce 1 Yogyakarta (Psychosocial stress status and its relationship with the nutritional status of Stella Duce 1 Junior High School students in Yogyakarta). Jurnal Gizi Klinik Indonesia, 6(3). https://doi.org/10.22146/ijen.17722

Tunurrohmin Z, Soemanto R, Pamungkasari
EP (2019). Path analysis on the determinants of depression symptom in elderly: a precede proceed model. J Public health. 4(4): 351-36o. https://doi.org/10.26911/jepublichealth.2019.04.04.10

Voelker DK, Reel JJ, Greenleaf C (2015). Weight status and body image perceptions in adolescents: current perspectives. adolescent health, medicine and therapeutics. Adolescent Health, Medicine and Therapeutics,6: 149-158. doi:10.2147/AHMT.S68344

Wong JL, Lim PY, Soon LK, LimZX (2018). Knowledge of nutrition during pregnancy and associated factors among antenatal mothers. IJPHCS, 5(1), 118128. Retrieved from: http://publichealthmy.org/ejournal/ojs2/index.php /ijphcs/article/view/531/438

Zaki I, Sari HP, Farida (2017). Asupan zat gizi makro dan lingkar lengan atas pada remaja putri di kawasan perdesaan kabupaten banyumas (Macro nutrient intake and upper arm circumference in young women in rural areas of Banyumas Regency. Prosiding Seminar Nasional: Pengembangan Sumber Daya Perdesaan dan Kearifan Lokal Berkelanjutan. Retrieved from: http://jurnal.lppm.unsoed.ac.id/ojs/index.php/Prosiding/article/view/535 